\title{
Kontras Luminansi Pada Pencahayaan Secondary Skin Studi Kasus : Fasade Mal Taman Anggrek, Jakarta
}

\author{
Augustina Ika Widyani ${ }^{1}$, Endah Setyaningsih ${ }^{2}$, Adi Ismanto ${ }^{3}$ \\ Fakultas Seni Rupa dan Desain Universitas Tarumanagara ${ }^{1,3}$, Fakultas Teknik Universitas Tarumanagara ${ }^{2}$ \\ augustinaw@fsrd.untar.ac.id
}

\begin{abstract}
Bangunan komersial Mal Taman Anggrek memiliki secondary skin pencahayaan buatan LED terbesar di dunia. Penelitian ini dilakukan sebagai evaluasi melalui proses observasi, wawancara dan kuesioner, terhadap hasil pencahayaan buatan setelah menggunakan secondary skin sebagai bagian dari konsep city beautification. Secondary skin yang digunakan pada Mal Taman Anggrek memungkinkan terjadinya gangguan dari pencahayaan yang atraktif dan dinamis terhadap pengguna jalan. Penelitian juga ditujukan untuk mengetahui sejauh mana penggaruh pencahayaan yang atraktif dan dinamis dari Mal Taman Anggrek dalam menghasilkan polusi cahaya terhadap pengguna bangunan atau kawasan sekitarnya. Selanjutnya penelitian juga dimaksudkan untuk mendapatkan data fisis atau data terukur luminansi dan distribusi luminansi mengenai tata cahaya kondisi eksisting sebagai awal proses evaluasi yang kemudian dianalisa melalui metode analisis sistemik yang meliputi tahap-tahap penguraian dan penyusunan data, penyimpulan serta rumusan hasil penelitian. Temuan dari penelitian ini disusun sebagai bahan evaluasi yang akan diketahui sejauh mana pengaruh penggunaan pencahayaan buatan pada secondary skin fasade bangunan komersial terhadap persepsi pengguna jalan dan pengaruhnya terhadap kawasan (bangunan sekitar).
\end{abstract}

Kata kunci: bangunan komersial, desain pencahayaan, persepsi visual, polusi cahaya, secondary skin fasade.

\section{PENDAHULUAN}

Lokasi strategis sebagaimana pada area komersial seperti Mal Taman Anggrek yang berdekatan dengan kepadatan lalu lintas, memiliki kelebihan dalam mendapatkan pengunjung sebanyak-banyaknya. Konsep city beautification menggunakan pencahayaan buatan yang atraktif dan dinamis mulai diimplementasikan pada bangunan komersial dengan tujuan untuk memperkuat citra sebuah bangunan pada kota urban. Hal ini mengakibatkan aktivitas di sekitar area komersial menjadi sangat padat dan kompleks bukan hanya sebagai jalur lalu lintas kendaraan tapi juga sebagai jalur pedestrian yang besar. Untuk memenuhi kebutuhan aktivitas dan fasilitas tersebut maka pencahayaan arsitektural yang diperlukan bukan hanya untuk memenuhi konsep city beautification melalui pencahayaan yang atraktif dan dinamis, tetapi juga harus dapat memenuhi aspek keselamatan (safety), orientasi (information) dan keamanan (security).

Penelitian terhadap polusi cahaya pernah dilakukan oleh Ming Liu dan Jiang Ma (Ming, Yue Fan; Baogang Zhang Jian Ma, 2012), juga oleh Ismanto (Ismanto, 2012). Indeks polusi cahaya pada pencahayaan jalan umum dan fasade bangunan telah dikaji oleh Saraiji (Riad 
Saraiji Ph.D. ; M. Saju Oommen, 2012). sebagai partisipan dipilih dengan metode Penelitian secondary skin pada Mal Taman Anggek lebih khusus meneliti tentang kontras iluminasi dan pengaruhnya kepada lingkungan yang memiliki aktifitas dengan intensitas tinggi.

Evaluasi Paska Huni (POE) pencahayaan pada pada secondary skin fasade bangunan komersial Mal Taman Anggrek yang menggunakan konsep city beautification dilakukan untuk mengetahui sejauh mana pencahayaan pada kawasan tersebut dapat mempengaruhi atau menganggu aktivitas dari pengguna kendaraan dan pengguna lainnya serta bagaimana mendapatkan data fisis mengenai kondisi pencahayaan di kawasan tersebut dengan melakukan pengukuran luminansi dan distribusi luminansi untuk mengetahui kondisi pecahayaan saat ini. Pengamatan secara objektif menggunakan data standar kontras luminansi, sementara pengamatan subjektif juga dilakukan melalui wawancara, dan survei/kusioner untuk didapat $P O E$ dan diketahui perlu tidaknya melakukan penyesuaian desain pencahayaan di lapangan.

\section{METODE}

Desain penelitian ini adalah deskriptif

\section{HASIL DAN PEMBAHASAN}

\section{Fasade Bangunan Komersial}

Fasade merupakan elemen arsitektur terpenting yang mampu menyuarakan fungsi dan makna sebuah bangunan. Fasade tidaklah semata-mata mengenai memenuhi "persyaratan alami" yang ditentukan oleh organisasi dan ruang dibaliknya. Fasade menyampaikan keadaan budaya saat bangunan itu dibangun; fasade mengungkap kriteria tatanan dan penataan, dan berjasa kualitatif. Subyek penelitian yang bertindak 
memberikan kemungkinan dan kreativitas dalam ornamentasi dan dekorasi.

Akar kata "fasade" (façade) diambil dari kata latin "facies" yang merupakan sinonim dari "face" (wajah) dan „appearance' (penampilan). Oleh karena itu, fasade dapat diartikan sebagai bagian luar bangunan yang menghadap ke jalan. Pada perkembangannya fasade sebuah bangunan tidak hanya terdiri dari satu bagian saja tetapi dapat diapresiasi dari berbagai sisi (depan, samping, belakang dan atas).

\section{Elemen Pembentuk Fasade dan Secondary}

\section{Skin Fasade}

Elemen pembentuk fasade sebuah bangunan (Herve Descottes; Cecilia E. Ramos, 2009) dapat dilihat dari tujuh sifat bentuknya, yang terdiri dari:

1. Wujud

Wujud memperlihatkan sisi luar karakteristik konfigurasi permukaan suatu bentuk tertentu, yang merupakan aspek utama atau sarana pokok di mana bentuk-bentuk dapat diidentifikasikandan dikategorikan, sehingga gambar yang muncul dapat dikenal. Dalam arsitektur, manusia berkonsentrasi dengan wujud yang terdiri dari: a. Bidang lantai, dinding dan langitlangit yang membatasi ruang.

b. Bukaan-bukaan jendela dan pintu di dalam ruang tertutup.

c. Bayangan-bayangan (sillhoutte) dan kontur bentuk bangunan.

Garis pertemuan antara massa dan ruang dapat mengekspresikan bagaimana sifat dasar kontur massa bangunan yang timbul dari bidang tanah ke atas.

2. Dimensi

Dimensi fisik suatu bentuk dapat berupa panjang, lebar dan tebal. Dimensi ini menentukan proporsi dari bentuk, sedangkan skalanya ditentukan oleh ukuran relatifnya terhadap bentukbentuk lain dalam konteksnya.

3. Warna

Warna merupakan sebuah fenomena pencahayaan dan persepsi visual yang menjelaskan persepsi individu dalam corak, intensitas dan nada. Warna adalah atribut yang paling menyolok dalam membedakan suatu bentuk dari lingkungannya. Warna juga mempengaruhi bobot visual dari suatu bentuk.

4. Tekstur

Tekstur adalah kualitas yang dapat diraba dan dapat dilihat yang diberikan ke 
permukaan oleh ukuran, bentuk, pengaturan dan proporsi bagian benda. Tekstur juga menentukan sampai mana permukaan suatu bentuk memantulkan atau menyerap cahaya yang datang.

5. Posisi

Letak dari sebuah bentuk adalah relatif terhadap lingkungan visual di mana bentuk tersebut terlihat.

6. Orientasi

Arah dari sebuah bentuk relatif terhadap bidang dasar, arah mata angin, bentukbentuk benda lain, atau terhadap seseorang yang melihatnya.

7. Inersia Visual

Inersia visual merupakan tingkat konsentrasi dan stabilitas suatu bentuk tergantung pada geometri dan orientasinya terhadap bidang dasar, gaya tarik bumi, dan garis pandangan manusia.

\section{Obyektif Desain Pencahayaan Arsitektural}

Dalam melakukan perancangan pencahayaan arsitektural terdapat 4 hal obyektif yang harus diperhatikan (Zumtobel, 2012) dan (Erco Guide for Outdoor Lighting, 2012), yaitu:

a. City beautification, pencahayaan arsitektural dapat membentuk citra dari suatu kawasan atau kota, yang kemudian mampu menarik perhatian dan mendatangkan wisatawan dan meningkatkan status (gengsi). Sehingga dapat dikatakan bahwa pencahayaan arsitektural mampu menciptakan nilai tambah budaya.

b. Memfasilitasi orientasi, keamanan dan keselamatan, dari sudut pandang psikologi persepsi dan desain, pencahayaan arsitektural merupakan elemen kunci dalam konsep pencahayaan malam hari dari suatu kawasan atau kota. Permukaaan vertikal dari suatu kawasan atau perkotaan berkontribusi signifikan terhadap definisi pengelompokan, ruang lalu lintas dan bangunan, sehingga mampu memfasilitasi orientasi, keamanan dan keselamatan. Dalam hal ini aplikasi rasio luminansi antara bidang permukaan atau area dalam bidang sudut pandang sangat penting untuk diperhatikan.

c. Menyampaikan pesan (sebagai sebuah faktor marketing), kota-kota di dunia menggunakan banyak kegiatan untuk mempromosikan pariwisata, membuat lokasi bisnis yang menarik atau membentuk sebuah distrik perumahan. Pencahayaan arsitektural pada malam hari merupakan salah satu cara terbaik 
untuk meningkatkan daya tarik dari ruang publik untuk meningkatkan pendapatan kawasan atau kota.

d. Mengkomunikasikan emosi dan menciptakan perhatian, pencahayaan arsitektural untuk beberapa tipe bangunan juga dapat menciptakan suasana atau mood dari persepsi pengunjung sesuai dengan kejadian tertentu sehingga mampu menciptakan perhatian.

Observasi dan Pengukuran luminansi dilakukan untuk mengetahui apakah implementasi pencahayaan pada secondary skin fasade memiliki luminansi sesuai dengan kriteria dari SNI pencahayaan buatan (Standar Nasional Indonesia, Pencahayaan Buatan, 2001) dan (Standar Nasional Indonesia, Sistem Pencahayaan, 2011) ataukah sebaliknya. Hasil pengukuran luminansi dapat dilihat pada

\section{Tabel 1}

Tabel V.1 Data fisis luminansi

\begin{tabular}{ll}
\multicolumn{1}{c}{ Arah Jalan } & Luminansi \\
\hline Menuju lobby utama Mal Taman & $2,7 \mathrm{~cd} / \mathrm{m} 2$ \\
Anggrek & \\
\hline Menuju Tol Jakarta-Merak & $2,1 \mathrm{~cd} / \mathrm{m} 2$ \\
\hline Menuju Grogol & $2,3 \mathrm{~cd} / \mathrm{m} 2$ \\
\hline Menuju Slipi & $1,4 \mathrm{~cd} / \mathrm{m} 2$ \\
\hline Menuju Harmoni /Tomang & $2,1 \mathrm{~cd} / \mathrm{m} 2$ \\
\hline
\end{tabular}

Sumber : dokumen tim peneliti, 2016
Berdasarkan observasi lapangan dan pengambilan data fisis luminansi di atas, dapat diambil kesimpulan bahwa screen LED menghasilkan luminansi yang berbeda-beda tergantung warna lampu yang ditampilkan dari screen LED. Rekomendai SNI untuk perbandingan luminansi di jalan raya antara jalan dan lampu maksimal adalah 1,5 cd/m2. Kontras yang dihasilkan oleh screen LED dengan lingkungan sekitar (langit malam) sangat besar, yaitu maksimal $1: 2,7 \mathrm{~cd} / \mathrm{m} 2$ (untuk bidang lampu warna putih). Hal ini sangat memungkinkan untuk terjadinya silau apabila dilihat oleh mata manusia.

Data fisis luminansi pada Tabel 1 memperlihatkan perbedaan kontras antara lingkungan sekitar Mal Taman Anggrek (langit malam) dengan bidang screen LED cukup besar. Apabila screen LED menampilkan video grafis dengan perubahan warna yang drastis dari terang ke gelap dan atau dari gelap ke terang, maka akan dapat membuat shock teraphy pada mata manusia, karena dikagetkan dengan perubahan pencahayaan yang cepat dari kondisi retina mata skotopik (sel batang yang aktif ketika cahaya sedikit) ke kondisi fotopik (sel kerucut yang aktif ketika cahaya banyak) atau sebaliknya yang menyebabkan mata manusia harus cepat 
beradaptasi dengan perubahan pencahayaan tersebut.
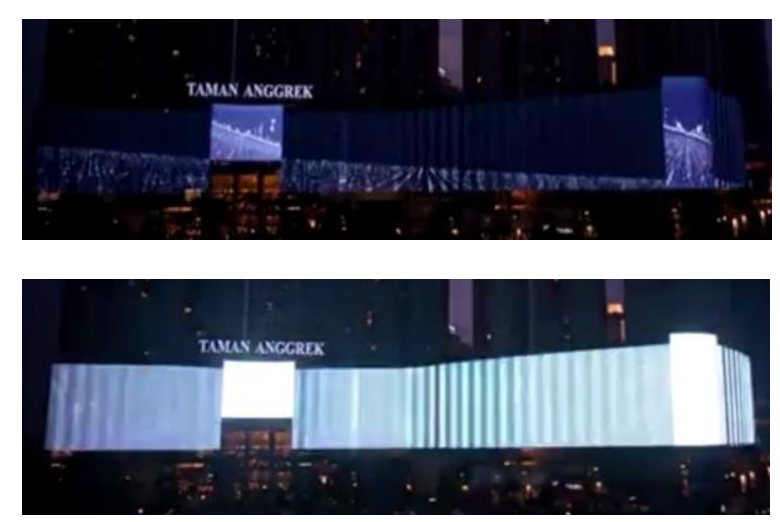

Gambar 1. Perubahan luminansi dari bidang gelap ke terang dengan perbandingan luminansi $0,6: 2,7$ candela/m2

Sumber: dokumentasi tim peneliti, 2016

Perubahan cahaya yang drastis tersebut membuat mata harus bekerja keras untuk beradaptasi dengan kondisi pencahayaan gelap ke terang atau sebaliknya (Bachman, 2011). Kondisi mata yang kaget atau kesulitan untuk beradaptasi memungkinkan terjadinya silau langsung apabila dilihat oleh manusia. Ditambah juga dengan tampilan visual pada screen LED dengan video grafis yang atraktif dan dinamis sehingga menstimulus pengguna jalan untuk melihat visual gambar yang ada. Dalam kondisi berkendara akan memungkinkan untuk mengakibatkan kecelakaan karena bisa menganggu konsentrasi saat berkendara, hipotesis ini akan dibuktikan melalui pengambilan sampel berupa kuesioner kepada pengguna jalan raya di kawasan Mal Taman Anggrek, dan juga diskusi terarah dengan ahli lighting, mahasiswa dan akademisi.

Sekitar 25 kuesioner dibagikan kepada masing-masing pengguna jalan raya (pejalan kaki dan pengendara kendaraan bermotor mobil dan motor melalui jalan biasa dan jalan tol) yang terdiri dari $60 \%$ partisipan berusia 17-28 th, dan $40 \%$ partisipan berusia $28-50$ th. Dari pejalan kaki didapatkan $100 \%$ partisipan memberikan penilaian menarik/ bagus pada layar LED screen mal Taman Anggrek. Sementara dari pengguna jalan raya (pengendara) $90 \%$ partisipan menilai menarik/ bagus, sementara $10 \%$ menilai baik. Hasil kuisioner yang lain dapat dilihat dari tabel berikut di bawah ini.

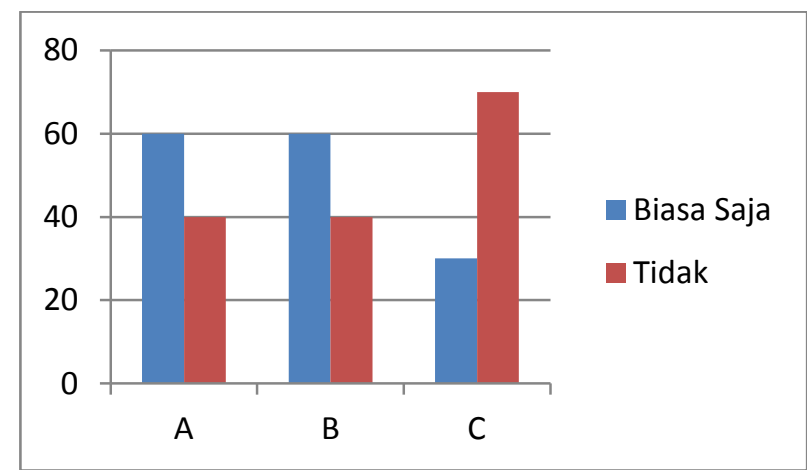

A : Terganggu dengan video grafis

$B$ : Kaget dengan perubahan warna dan kontras C : Silau

Gambar 2. Diagram respons pejalan kaki terhadap LED Mal Taman Angrek Sumber: dokumentasi tim peneliti, 2016 


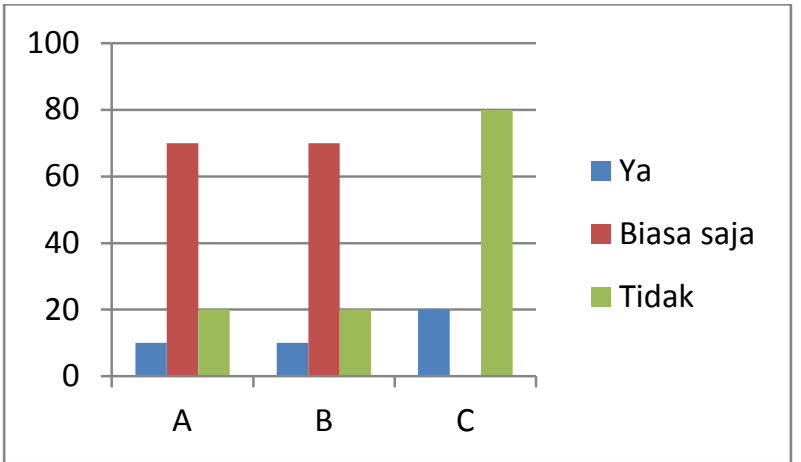

A : Terganggu dengan video grafis

B : Kaget dengan perubahan warna dan kontras C : Silau

Gambar 3. Diagram respons pengguna jalan raya terhadap LED Mal Taman Angrek Sumber: dokumentasi tim peneliti, 2016

Dari hasil kuisioner yang disebarkan kepada partisipan, ternyata tidak ada pejalan kaki yang merasa terganggu dengan kondisi pencahayaan yang bersifat atraktif dan dinamis dari screen LED Mal Taman Anggrek, $60 \%$ mengatakan biasa saja dan $40 \%$ mengatakan tidak terganggu. Sedangkan penggendara motor maupun mobil sebanyak $70 \%$ mengatakan biasa saja, 20\% mengatakan tidak terganggu dan ada $10 \%$ yang mengatakan terganggu. Tingkat konsentrasi pengedara motor dan mobil lebih tinggi untuk memperhatikan jalan dibandingkan pejalan kaki.

Tidak ada pejalan kaki yang merasa kaget dengan perubahan pencahayaan dari kondisi gelap ke terang atau sebaliknya dari screen LED Mal Taman Anggrek, 60\% mengatakan biasa saja dan $40 \%$ mengatakan tidak kaget.
Sedangkan penggendara motor maupun mobil sebanyak $70 \%$ mengatakan biasa saja, $20 \%$ mengatakan tidak terganggu dan ada $10 \%$ yang mengatakan kaget. Perubahan pencahayaan dari gelap ke terang atau sebaliknya akan membuat mata sulit beradaptasi dengan cepat apabila langsung melihat ke sumber cahayanya.

Ada sedikit perbedaan pendapat tentang silau yang terjadi dari screen LED Mal Taman Anggrek, sebanyak 20\% pengendara motor dan mobil menganggap terjadi sliau dan $80 \%$ menganggap tidak terjadi silau. Sedangkan pejalan kaki sebanyak $30 \%$ mengatakan terjadi silau dan $70 \%$ mengatakan terjadi silau. Pejalan kaki memiliki waktu lebih banyak untuk melihat langsung pencahayaan yang berubah-ubah dari screen LED Mal Taman Anggrek, terkadang ada yang berhenti untuk dapat menikmati sesaat saja, dibandingkan pengendara motor dan mobil yang lebih memperhatikan jalan raya.

\section{SIMPULAN}

Renovasi fasade bangunan Mal Taman Anggrek dianggap berhasil memberikan perubahan atau kesan visual bangunan dengan menggunakan screen LED sebagai secondary skin fasade yang meberikan kesan modern, atraktif dan dinamis. Pada malam hari, pencahayaan dari screen LED menjadi 
sangat menarik untuk dinikmati oleh pengguna jalan di sekitar kawasan Mal Taman Anggrek, bahkan Mal Taman Anggrek telah menjadi ikon bangunan di kota Jakarta.

Kontras luminansi dari pencahayaan lampu LED pada screen Mal Taman Anggrek memiliki perbandingan yang cukup besar dibandingkan dengan kondisi lingkungan sekitar pada malam hari, yaitu: 1:2,7 candela/m2 (dengan cahaya lampu putih terang). Sedangkan warna cahaya lain seperti ungu memiliki luminansi paling rendah yaitu 1,4 candela/m2. Perubahan pencahayaan pada bidang yang sangat besar ini dapat mempengaruhi lingkungan sekitar, terutama persepsi visual pengguna jalan raya.

Beberapa video grafis yang ditampilkan pada screen LED fasade Mal Taman Anggrek memiliki perubahan warna atau pencahayaan yang dinamis dan atraktif. Beberapa kondisi pencahayaan berubah sangat cepat dan drastis dari kondisi terang ke gelap ataupun sebaliknya. Pembuktian terjadinya gangguan pada pengguna jalan dapat dilihat dari hasil respon pengendara motor atau mobil yang mengatakan kaget dan terganggu dengan perubahan tersebut walaupun hanya sebanyak $10 \%$ yang memungkinkan untuk menyebabkan terjadinya kecelakaan pengendara motor atau mobil akibat gangguan tersebut.

Persepsi visual pengguna jalan terhadap screen LED Mal Taman Anggrek sangat baik, semua responden mengatakan senang dan tertarik untuk malihat pencahayaan yang dinamis dan atraktif dari video grafis yang ditampilkan. Hanya saja terjadi silau masih terjadi akibat pantulan maupun sliau langsung apabila melihat ke sumber cahaya, terutama untuk pejalan kaki karena ada beberapa faktor yang memungkinkan pejalan kaki untuk lebih lama menikmati video grafis tersebut.

Pencahayaan sebagai salah satu elemen penting dari bangunan tidak dapat diabaikan, hal ini menjadi perhatian penting dalam perancangan sebuah fasilitas publik dan komersial seperti Pusat perbelanjaan. Dalam hal ini secondary skin fasade Mal Taman Anggrek menggunakan screen LED menjadi ikon Jakarta, bahkan dianggap yang terbesar di dunia, sehingga mejadi sangat penting untuk memperhatikan tampilan visual grafis, akibat serta efisiensi dari cahaya yang dihasilkan.

Perlu dikaji mengebai perubahan pencahayaan dari video grafis yang tidak bersifat drastis atau cepat dari kondisi gelap ke terang atau sebaliknya.sangat 
memungkinakan untuk menampilkan video grafis yang tidak mengganggu lingkungan sekitar atau pengguna jalan dengan perubahan warna atau cahaya yang bersifat gradasi atau transisi dari gelap ke terang atau sebaliknya dengan waktu yang lebih pelan dan halus atau smooth.

Penelitian lanjutan dapat dilakukan pada bangunan lainnya yang menggunakan secondary skin fasade lampu LED ataupun papan billboard komerisal pada persimpangan jalan raya.

\section{DAFTAR PUSTAKA}

Erco Guide for Outdoor Lighting (updated version ed.). (2012).

Herve Descottes; Cecilia E. Ramos. (2009). Architectural Lighting: Designing with light and space. Germany.

Ismanto, A. (2012). Persepsi Modelling dan Pengaruh Warna pada Pencahayaan Fasade Bangunan Edutainment Istana Boneka Dufan Ancol. Bandung: Program Studi Magister Teknik Fisika, Institut Teknologi Bandung.

Ming, Yue Fan; Baogang Zhang Jian Ma. (2012). Investigation and Esperiment of Dynamic Light Disturbance. Dalian, China:
School of Architecture and Fine Art, Dalian University of Technology.

Riad Saraiji Ph.D. ; M. Saju Oommen. (2012). Light Pollution Index (LPI): An Integrated Approach to Study Light Pollution with Street Lighting and Facade Lighting.

Standar Nasional Indonesia, Pencahayaan Buatan. (2001).

Standar Nasional Indonesia, Sistem

Pencahayaan. (2011).

Zumtobel. (2012). Light For Education and Schience. Dornbirn, Austria. 